\title{
Article/Artigo
}

\section{Enteric parasites in HIV-1/AIDS-infected patients from a Northwestern São Paulo reference unit in the highly active antiretroviral therapy era}

\author{
Enteroparasitas em pacientes infectados pelo HIV-1/AIDS em uma unidade de referência do \\ noroeste paulista na era da terapia antirretroviral de alto impacto
}

Luciana Ventura Cardoso ${ }^{1}$, Katia Jaira Galisteu ${ }^{2}$, Arlindo Schiesari Júnior ${ }^{3}$, Luana Aparecida Oliveira Abou Chahla $^{1}$, Rafaela Moreira da Silva Canille ${ }^{1}$, Marcus Vinicius Tereza Belloto ${ }^{1}$, Célia Franco ${ }^{4}$, Irineu Luiz Maia ${ }^{4}$, Andréa Regina Baptista Rossit ${ }^{5}$ and Ricardo Luiz Dantas Machado ${ }^{1}$

\begin{abstract}
Introduction: We describe the epidemiology of intestinal parasites in patients from an AIDS reference service in Northeastern São Paulo, Brazil. Methods: Retrospective evaluation was done for all HIV-1/AIDS-positive patients whose Hospital de Base/São José do Rio Preto laboratorial analysis was positive for enteroparasites after diagnosis of HIV-1 infection, from January 1998 to December 2008. Statistical analysis was performed using the R statistical software version 2.4.1. The level of significance adopted was 5\%. Results: The most frequent protozoan was Isospora belli (4.2\%), followed by Giardia lamblia (3.5\%), Entamoeba coli (2.8\%), and Cryptosporidium parvum (0.3\%). Ancylostoma duodenale (1.4\%) was the most frequently detected helminth, while Taenia saginata and Strongiloides stercoralis were found in $0.7 \%$ of the samples. The results showed that diarrhea was significantly associated with giardiasis and isosporiasis. However, no association was observed between $\mathrm{CD}^{+}$cell counts, viral load, and the characteristics of any particular parasite. Conclusions: Our data may be useful for further comparisons with other Brazilian regions and other developing countries. The data may also provide important clues toward improving the understanding, prevention, and control of enteric parasites around the world.
\end{abstract}

Keywords: Epidemiology. HIV-1. AIDS. Enteroparasites. HAART. Brazil.

\section{RESUMO}

Introdução: Descrevemos a epidemiologia de enteroparasitoses em pacientes de um serviço de referência de AIDS, no noroeste paulista, Brasil. Métodos: Durante o período de janeiro de 1998 a dezembro de 2008, foi realizado este estudo retrospectivo por meio da análise dos prontuários dos pacientes diagnosticados com HIV-1/AIDS atendidos no Ambulatório de Doenças Infecto-Parasitárias do Hospital de Base, São José do Rio Preto, São Paulo. As análises estatísticas foram realizadas usando a versão 2.4.1 do software estatístico R. O nível de significância adotado foi de 5\%. Resultados: O protozoário mais frequente foi o Isospora belli $(4,2 \%)$, seguido da Giardia lamblia (3,5\%), Entamoeba coli $(2,8 \%)$ e Criptosporidium parvum (0,3\%). O Ancylostoma duodenalis (1,4\%) foi o helminto mais detectado, enquanto a Taenia saginata e o Strongiloides stercoralis foram observados em 0,7\% das amostras. Os resultados mostraram que a diarreia foi significativamente associada com giardíase e isosporíase. Entretanto, nenhuma associação foi observada entre as contagens de células T CD4 ${ }^{+}$, carga viral e da característica de qualquer parasita em particular. Conclusões: Nossos dados podem ser úteis para futuras comparações com outras regiões do Brasil e outros países em desenvolvimento. Os dados também podem fornecer pistas importantes para a melhoria da compreensão, prevenção e controle de parasitas entéricos em todo o mundo.

Palavras-chaves: Epidemiologia. HIV-1. AIDS. Enteroparasitas. HAART. Brasil.

1. Centro de Investigação de Microorganismos, Faculdade de Medicina de São José do Rio Preto, São José do Rio Preto, SP. 2. Departamento de Enfermagem Geral, Faculdade de Medicina de São José do Rio Preto, São José do Rio Preto, SP. 3. Curso de Medicina, Faculdades Integradas Padre Albino, Catanduva, SP. 4. Ambulatório de AIDS, Hospital de Base, São José do Rio Preto, SP. 5. Departamento de Microbiologia e Parasitologia, Universidade Federal Fluminense, Niterói, RJ.

Address to: Dra. Luciana Ventura Cardoso. CIM/FAMERP. Av. Brigadeiro Faria Lima 5416, Bloco U6, 15090-000 São José do Rio Preto, SP, Brasil.

Phone/Fax: 5517 3201-5736

e-mail: lu_famerp@hotmail.com

Received in 26/03/2011

Accepted in 20/05/2011

\section{INTRODUCTION}

HIV-1 infection is a disease that goes with progressive depression of the immune system; its symptoms appearance may vary, in general, from 6 months to 10 years. Acquired immune deficiency syndrome (AIDS) is the expression of the advanced form of the disease, characterized by the appearance of opportunistic diseases that can have infectious or neoplastic characteristics ${ }^{1}$. The prevalence of people living with HIV-1 has increased to 33.2 million in the last 3 years, and an estimated 22.1 million have died from diseases related to HIV-12.

In Latin America, a third of HIV-1-seropositive individuals live in Brazil. In the Southeast of the country, $67.8 \%$ of the cases are found ${ }^{1}$. The South leads with the number of deaths $(8.7 / 100,000$ inhabitants) in cases that $90 \%$ of people that live five years after the diagnosis ${ }^{2}$. However, there is a trend of increasing cases in the North $(16,103)$ and Northeast $(53,089)$, and of stabilization in the South $(89,250)$, Southeast $(289,074)$, and Central West regions (26,757). According to the World Health Organization (WHO), the concentration of the epidemic is in the population between 15 and 49 years old, with a prevalence of HVI-1 tax of infection of $0.6 \%{ }^{2}$.

Diarrhea stands out as one of the possible manifestations of AIDS, especially among patients who are immune depressive. Although there is relevance in the association between AIDS and diarrhea, there is scant literature available that explains the participation of enteric pathogens in this population. Some reports indicate the occurrence of diarrhea in $30-60 \%$ of patients with AIDS in developed countries and in $90 \%$ of cases in developing countries ${ }^{3}$. The relevance of enteropathogens as colonizers of gastrointestinal mucosa in HIV-1 is unquestionable. Diarrhea may or may not be infectious, but the first form occurs 
more frequently in developed countries, being more common than infections caused by viruses, bacteria, or protozoa. Independently of these reasons, intestinal parasite infections are the most studied in the group of HIV-1-seropositive/AIDS patients. Some opportunistic protozoan parasites, such as Cryptosporidium parvum, Isospora belli, and microsporídia contribute to chronic diarrhea, with resultant loss of weight in HIV/AIDS patients ${ }^{3}$. Besides, protozoa such as Giardia lamblia and Entamoeba histolytica and the helminths Strongyloides stercoralis, Ascaris lumbricoides, and Ancylostoma duodenale ${ }^{4-6}$ are regarded as the main pathogens that affect these patients.

We observe that the prevalence of enteroparasites in HIV/AIDS patients varies in many regions of the world, mainly influenced by seasonality ${ }^{7,8}$. The same holds true in Brazil. In the State of Ceará, in the Northeast, a greater prevalence of G. lamblia ${ }^{9}$ in patients and an association between diarrhea and the presence of $C$. parvum and Microsporidium ${ }^{10}$ are found. In the Southeast, contradictory results are observed, as studies done in the State of Rio de Janeiro showed no evidence of the presence of enteroparasites in the etiology of diarrhea. However, Cryptosporidium was the most commonly found, followed by G. lamblia, E. histolytica, and I. belli. On the other hand, two other studies in the States of Minas Gerais and São Paulo showed the presence of diarrhea in patients with I. belli, G. lamblia, and Cryptosporidium ${ }^{11,12}$. Few effects were attributed to helminths in the natural history and epidemiology of AIDS; although Strongyloidiasis has been more frequently described in Brazilian medical history, its prevalence in AIDS cases was $4.5 \%$ compared to $1.4 \%$ in the population in general ${ }^{12}$.

The definition of the cause of diarrhea in HIV patients is a challenge as this disease can be noninfectious; it is the most common collateral effect of highly active antiretroviral therapy (HAART) ${ }^{13}$. Since 1996, with the progressive introduction of HAART, which has helped control HIV-1 infection and reconstruct the immune system, changes have been observed in the profile of morbi-mortality among HIV-1/ AIDS patients, reflected in the reduction in opportunistic infections, including those caused by enteroparasites. A study conducted in the State of Ceara showed that with the use of HAART, the chances of being infected by enteroparasites became 5.6 times lower ${ }^{14}$.

Some studies about the hospitalization of HIV-1-seropositive patients have shown that gastrointestinal diseases constituted the main cause of hospitalization of patients about 41 years old ( 24 by 1,000 people per year). It was also shown that for each increase of 50 cells $/ \mathrm{mm}^{3}$ in the TCD4 $4^{+}$lymphocyte (LTCD4 ${ }^{+}$) counts, there was an $8 \%$ reduction in the risk of hospitalization. Even under the use of HAART, hospitalization rates remained the same while comorbidities did change ${ }^{15}$. Therefore, this study aims to describe the epidemiology of intestinal parasitosis in HVI-1-seropositive patients in a hospital located in the Northeast of the State of São Paulo.

\section{METHODS}

This retrospective, transversal, and descriptive study was conducted during the period January 1998 to December 2008, in the HAART era, to analyze the medical forms of HIV-1/AIDS patients at the ambulatory for infectious and parasitic diseases at Hospital de Base, located in the City of São Jose do Rio Preto in the State of São Paulo, Brazil. Hospital de Base is a hospital school associated with the courses of medicine and nursery of the Faculdade de Medicina de São José do Rio Preto (FAMERP). This hospital has 800 berths available to the Brazilian public health system (SUS), has level 4 specialized attendance, is controlled by the State of São Paulo, and receives patients from 101 cities in the Northwest of São Paulo. The City of São Jose do Rio Preto is located $443 \mathrm{~km}$ from the City of São Paulo ${ }^{16}$, and its population is about $420,000^{17}$.

During the period of 10 years, 1,100 patients were registered at the ambulatory of infectious and parasitic diseases, and 300 (27\%) of the forms were inactive for a period over 3 years. Among the active forms, only 500 were used for the enteroparasite analysis. The data were collected using a questionnaire with the following items: age, sex, category of virus exposure, information about antiretroviral treatment, laboratory exams, clinical criteria for diarrhea, and parasitological fecal exam.

The exams were done at the Hospital de Base laboratory, and the fecal samples were analyzed using microscopic methods to detect eggs, larvae, and cysts. The methods of Hoffman, Pons and Janer, Faust, and Baermann-Moraes were used. The modified Ziehl-Neelsen stain was also used to microscopically identify C. parvum and I. belli. A stool sample was collected from each patient. Each participant was provided with a standard fecal collection vial containing $4 \mathrm{~mL}$ of $5 \%$ formalin and a spatula. Approximately $10 \mathrm{~g}$ of feces was obtained for the parasitological analysis. The lamina analysis was done using an optical microscope, with 10x and 40x objective lenses. The patients' anti-HIV antibodies as detected by enzyme-linked immunosorbent assay (ELISA) or Western blot (Wb), viral load (VERSANT HIV-1 RNA 3.0 bDNAAssay, Siemens, Bayswater, Victoria, Australia), and immunological profile (Tritest CD4FITC/CD8 PE/CD3 PerCP, Becton Dickinson, CA) were obtained from the medical forms. Statistical analyses were made using the R statistical software version 2.4.1. (R Foundation, ISBN 3-900051-070, http://www.r-project.org, Vienna, Austria). To obtain interdependence among proportions, chi-square distribution and Fisher's exact tests were used. The statistical significance level was 5\%.

\section{Ethical considerations}

The study was approved by the ethics and research council of FAMERP (protocol \#3361/2008) according to resolution 196/96.

\section{RESULTS}

The average age of the HIV-1 patients was 42.3 years, and most of them were men (61.2\%). Heterosexual relationship was the main cause of the disease in this period. Among the male patients, sexual relationships were the main source of HIV infection $(32.7 \%$ had sex with women), while nonsexual behaviors were less causative. A significant association was observed among women infected through sexual relations (chi-square, $\mathrm{p}<0.0001$ ). The risk of being infected by parental transfusion was more significant among men (chi-square, $\mathrm{p}=0.0004)$. The smallest risk of infection was in haemophilia (0.3\%). There was no observed relationship between gender and haemophilia.

As shown in Table 1, there is an association between diarrhea and the use of HAART in the parasitological exam results for HIV-1/ AIDS patients. Among those who presented a negative result on the exam, $416(86.5 \%)$ patients had used HAART, and 125 (26\%) patients had had diarrhea $(\mathrm{p}=0.0001)$. Among the fecal samples tested, 19 (3.8\%) were positive for enteroparasites, and 18 (94.7\%) were classified as diarrhea, corresponding to $3.6 \%$ of all patients. A significant association was observed only between the presence of enteroparasites and the diarrheic fecal aspect (Fisher's exact test, $\mathrm{p}>0.0001$ ).

The association between the presence of parasites and the fecal aspect in the HAART era is shown in Table 2. Most of the individuals did not have diarrhea (71.2\%); there was a concomitance 
TABLE 1 - Clinical characteristics of the HIV-1/AIDS patients and the parasitological results in the HAART era, São José do Rio Preto, Brazil, 2011.

\begin{tabular}{|c|c|c|c|c|}
\hline \multirow[b]{3}{*}{ Variable } & \multicolumn{4}{|c|}{ Fecal parasitologic evaluation } \\
\hline & \multicolumn{2}{|c|}{ positive } & \multicolumn{2}{|c|}{ negative } \\
\hline & $\mathrm{n}$ & $\%$ & $\mathrm{n}$ & $\%$ \\
\hline \multicolumn{5}{|l|}{ Access to HAART } \\
\hline patients using & 18 & 94.7 & 416 & 86.5 \\
\hline patients not using & 1 & 5.3 & 84 & 17.5 \\
\hline total & 19 & 100.0 & 481 & 100.0 \\
\hline \multicolumn{5}{|l|}{ Diarrhea status } \\
\hline yes & $18^{*}$ & 94.7 & 125 & 26.0 \\
\hline no & 1 & 5.3 & 356 & 74.0 \\
\hline total & 19 & 100.0 & 481 & 100.0 \\
\hline
\end{tabular}

*Fisher's exact test: $\mathrm{p}=0.0001$; HAART: highly active antiretroviral therapy.

TABLE 2 - Association between the presence of parasites and the fecal aspect, São José do Rio Preto, Brazil, 2011.

\begin{tabular}{|c|c|c|c|c|c|}
\hline \multirow[b]{4}{*}{ Enteroparasites } & \multicolumn{4}{|c|}{ Fecal aspect } & \multirow[b]{4}{*}{ Pvalue* } \\
\hline & \multirow{2}{*}{\multicolumn{2}{|c|}{$\frac{\text { non-diarrheic }}{(\mathrm{n}=357)}$}} & \multirow{2}{*}{\multicolumn{2}{|c|}{$\frac{\text { diarrheic }}{(n=143)}$}} & \\
\hline & & & & & \\
\hline & $\mathrm{n}$ & $\%$ & $\mathrm{n}$ & $\%$ & \\
\hline Giardia lamblia & - & & 5 & 3.5 & 0.0023 \\
\hline Cryptosporidium parvum & 1 & 0.3 & - & & \\
\hline Isospora belli & - & & 6 & 4.2 & 0.0007 \\
\hline Endolimax nana & - & & 3 & 2.1 & \\
\hline Entamoeba coli & - & & 4 & 2.8 & \\
\hline Ancylostoma duodenale & - & & 2 & 1.4 & \\
\hline Taenia saginata & - & & 1 & 0.7 & \\
\hline Strongyloides stercoralis & - & & 1 & 0.7 & \\
\hline None & 99.7 & & 125 & 7.4 & \\
\hline
\end{tabular}

between two parasites in four fecal samples. The positive results for enteroparasites were observed mainly in samples with diarrhea; the mean number of enteroparasites found was 1.21 for each positive fecal sample. In the diarrheic samples, the more frequent protozoan was Isospora belli (4.2\%), followed by Giardia lamblia (3.5\%), Entamoeba coli (2.8\%), and Endolimax nana (2.1\%). In only one non-diarrheic sample was Cryptosporidium parvum (0.3\%) found. Ancylostoma duodenale (1.4\%) was the most frequently detected helminth, while Taenia saginata was observed in $0.7 \%$ of samples. Only one sample presented Strongyloides stercoralis, and it was from a male patient. There was a significant association between diarrhea and the presence of G. lamblia and I. belli (Fisher's exact test, $\mathrm{p}=0.0023$ and $\mathrm{p}=0.0007$, respectively).

The TCD4+ lymphocyte count (obtained up to 3 months before or after fecal analysis) was available only for 14 of the 19 patients because of the absence of this information in the medical forms. The detection was verified in patients with lymphocyte levels of 200-350 LTCD4+ (33.3\%) and < 200 LTCD4+ (50\%). Among patients with a HIV-1 viral load > $100.000 \mathrm{copy} / \mathrm{mL}$, Isospora belli was detected in three cases. Among individuals with a viral load of 10.000-100.000 copy/mL, the presence of Entamoeba coli and Giardia lamblia was observed. In patients with a superior viral load, only the nonpathogenic amoeba Endolimax nana was found. No statistically significant association was observed between the LTCD4+ level and viral load and the presence of enteroparasites.

\section{DISCUSSION}

There is no uniformity in the dissemination of HIV-1, which shows different behaviors in different regions of the world. Here we discussed the epidemiologic aspects of enteroparasites in a HIV-1seropositive adult population at a hospital in the Northwest of the State of São Paulo.

The results presented in this study showed that the HIV1 infection was mainly among male individuals in their $40 \mathrm{~s}$ (42.3 years), which is in accordance with the reports of national media ( 40 and 59 years) and associated with the increase in life expectancy ${ }^{18}$. The data on the method of transmission of HIV-1 confirm those found in the other regions of the country, in which sexual relations was predominant ${ }^{19,20}$, especially among individuals with a low level of education. Intestinal parasite infection presents a problem among HIV-1 patients because of the decreased immunity and the infestation by pathogenic microorganisms, which may result in diarrhea ${ }^{20,21}$. Data on the LTCD $4^{+}$count were found only in some forms; therefore, no inference could be made. However, if the association between diarrhea and AIDS occurs because of an alteration in the immunologic system, this should not occur as a result of an immune dysfunction presented by LTCD4 ${ }^{+}$cells, as shown in another study in a HIV-1-seropositive Brazilian population'. One of the possible collateral effects of HAART, especially of the protease inhibitors, is diarrheic manifestation ${ }^{14}$. However, protease inhibitor therapy and viral load may also not be related to gastrointestinal dysfunction in the population analyzed.

In this study, it was verified that the protozoan I. belli was the most frequently found in HIV-1-seropositive patients; however, the indices were lower than 5\%. Curiously, these data confirmed similar indices observed in a prospective study in this same population 7 years ago ${ }^{22}$. According to previous studies ${ }^{1,13}$, I. belli has been detected with low frequency in AIDS patients; this can occur because of the liberation of immature oocysts in a noncontinuous way, which may not correspond to the asymptomatic period and may not be eliminated in the first phase of the infection, when the signs and symptoms become evident ${ }^{13}$. Besides, there are some difficulties in the diagnoses of I. belli as there is a fluctuation in the gastrointestinal macrobiotic or enteropathogenic agents, probably because of chemoprophylactic therapy or treatment ${ }^{14}$. Furthermore, the specific techniques for the diagnosis of this protozoan are not routinely performed in the laboratories in this region.

Concerning the prevalence of G. lamblia, our study showed that, although this parasite was the second most commonly detected, it did not occur with excessive frequency, only in $3.5 \%$ of all diarrheic samples. This fact caught our attention because in some regions of São Paulo, up to $40 \%$ of the population carries this protozoan but without apparent symptoms ${ }^{12}$. On the other hand, the low frequency of this infection may be related to the fact that the elimination of the parasite forms of this protozoan is intermittent ${ }^{23}$. The low frequency of $G$. lamblia persists based on the national data, and is confirmed by all the data from prior studies about HIV-1-seropositive patients in the Northwest of São Paulo ${ }^{22,24}$. Consequently, this retrospective study affirms the position that this protozoan does not present relevant expression in the HIV population in this part of São Paulo. Although G. lamblia was associated with diarrhea, the mechanisms by which this parasite disturbs and lowers intestinal absorption are still subjects for further investigation. We believe that these actions are multifunctional, involving both the pathogen and the host ${ }^{25}$. 
Cryptosporidium parvum has been found in 6\% of $94 \%$ of HIV-1 patients in developing countries ${ }^{26,27}$, and according to the Brazilian Health Ministry, its official global prevalence is $0.7 \%{ }^{28}$. The infection caused by Cryptosporidium sp. in HIV-1/AIDS patients has been attributed to the immune system reconstitution by HAART, even in patients without specific treatment for the parasite ${ }^{29-31}$. Besides, both the in vivo and the in vitro evidence shows that the control of cryptosporidiosis in patients under HAART is caused by protease inhibitors ${ }^{32-34}$, which could be interfering with this protozoan`s aspartyl protease function ${ }^{35}$. In this study, only one case of cryptosporidiosis was identified in a non-diarrheic sample. With regard to previous data in the region of detection in adults $(9 \%)^{36}$ and children $(62 \%)^{22}$, we note that this profile can be related to age, which influences the distribution of the parasite, and the fact that the modified Ziehl-Neelsen stain does not normally detect this parasite as described for I. belli.

Ancylosotma duodenale, Taenia saginata, and Strongyloides stercoralis were detected in this study but with low frequency. Immune depression in human hosts has a less relevant impact on helminth parasites than on protozoa ${ }^{37}$. However, besides the chronic immune sequels, there is a hypothesis that Th2 lymphocyte polarization that follows helminths can have a relevant role in the HIV infection pathogenesis by the preferential virus application in these cells, increasing lymphocyte apoptosis and acting as a stimulus for viral co-receptors ${ }^{38}$. The pattern of $A$. duodenale infection has been verified, and although few studies have reviewed HIV patients that did not present a intestinal dysfunction, such as diarrhea, these hosts act as means of transportation through water and defecation. Besides, the nematode worms presented in the intestinal cells present low relevance because of the physical maintenance of the mucosa and immune local response $\mathrm{e}^{27}$. In relation to cestodes, few studies associated immune depression to these helminths. In addition, they did not present any alterations in AIDS patients' clinical patterns. However, immune depression may benefit the presence of the parasite, reducing spontaneous cure. In the case of T. solium, immune depression and transplants can make cases of cysticercosis worse ${ }^{39}$.

Undoubtedly, the particularities of $S$. stercoralis are well described in the medical literature. HIV-1 immune depression reinforces the infection caused by $S$. stercoralis and can be favorable to the dissemination of filarial larvae, which can reach the intestines, lungs, and other organs ${ }^{40}$. However, there is a controversy regarding the origin of this manifestation, whether it is related to the viral infection per se or arises from other factors that are inherent to HIV-1 patients, such as the use of steroids, inanition, or coinfection by HIV- $1^{41}$. A recent study showed that HIV-induced immune depression hindered the multiplication of infectious larvae in the intestine, a necessary condition for hyperinfection ${ }^{42}$. Nevertheless, in tropical and subtropical countries, the occurrence of severe strongyloidiasis in the HIV-1 infected group is noticed and may, therefore, aggravate the infection by this virus ${ }^{43}$. Because of the reduced number of cases of S. stercoralis hyperinfection syndrome in AIDS patients, in 1987 the Center for Disease Control and Prevention (CDC) excluded this disease from the list of AIDS opportunist diseases.

Cryptosporidiosis, Strongyloidiasis, giardiasis, and isosporiasis are the most common parasitoses in patients infected by HIV-1 living in the Northwest of São Paulo. The results indicate that enteroparasitoses are the most important causes of death among infected patients, especially those caused by I. belli and G. lamblia. The diarrhea etiology for adults seropositive for HIV-1 in this region is not associated with HAART, but the intestinal clinical complications may be related to other enteropathogens, such as viruses, bacteria, fungi, and other emergent coccidian. In addition, the low prevalence of these enteroparasites may be linked to HAART since antiretroviral therapy can change the profile of parasite infections, probably because of the reconstitution of cell immunity and the action of these drugs on parasites ${ }^{14}$ even in individuals with no specific therapy for enteric parasites ${ }^{44}$. Investigations are currently being undertaken in our laboratory to clarify the role of diverse enteropathogenic agents in noninfected HIV-1 individuals.

A possible limitation of this study may be related to factors, such as confusion, mainly due to incomplete forms or therapeutic administration prior to fecal parasitologic evaluation. Although the data analyzed are representative of a community of HIV-1 patients in the Northwest of São Paulo, they can be used in further studies for comparisons with other regions of Brazil and developing countries. Furthermore, the data provide important insights toward improving the understanding, prevention, and control of parasites in HIV-1 patients all over the world. Even with the recent developments in this field, enteroparasitoses are still a public health problem, mainly in developing countries. Besides, the presence of the above-mentioned parasites in HIV-1 patients can stimulate new cases of enteroparasitoses because the patients function as hosts.

\section{ACKNOWLEDGMENTS}

The authors thank the HIV-1/AIDS patients included in this study and the Hospital de Base staff. We also thank Valéria Daltibari Fraga and Luciana Moran for their administrative support during the data collection.

\section{CONFLICT OF INTEREST}

The authors declare that there is no conflict of interest.

FINANCIAL SUPPORT

Faculdade de Medicina de São José do Rio Preto.

\section{REFERENCES}

1. UNAIDS [Internet]. Report on the global AIDS epidemic. [cited Apr 2008 11]. Available from: www.unaids.org.

2. Ministério da Saúde. Departamento de Vigilância Epidemiológica [Internet]. Programa Nacional de DST e AIDS: Bulletin Epidemiological of Sexually Transmitted Disease Program/AIDS. 2007 - [cited Aug 2007 01]. Available from: www.aids.gov.br

3. Chawla R, Ichhpujani RL. Enteric spore-forming opportunistic parasites in HIV/ AIDS. Trop Parasitol 2011; 1:15-19.

4. Dwivedi KK, Prasad G, Saini S, Mahajan S, Lal S, Baveja UK. Enteric opportunistic parasites among HIV infected individuals: associated risk factors and immune status. Jap J infect Dis 2007; 60:76-81.

5. Hung CC, Deng HY, Hsiao WH, Hsieh SM, Hsiao CH, Chen MY, et al. Invasive amebiasis as an emerging parasitic disease in patients with human immunodeficiency virus type 1 infection in Taiwan. Arch intern Med $2005 ; 165: 409-415$

6. Ramakrishnan K, Shenbagarathai R, Uma A, Kavitha K, Rajendran $\mathrm{R}$, Thirumalaikolundusubramanian P. Prevalence of intestinal parasitic infestation in HIV/AIDS patients with diarrhea in Madurai City, South India. Jap J infect Dis 2007; 60:209-210. 
7. Cárcamo C, Hooton T, Wener MH, Weiss NS, Gilman R, Arevalo J, et al. Etiologies and manifestations of persistent diarrhea in adults with HIV-1 infection: a casecontrol study in Lima, Peru. J Infect Dis 2005; 191:11-19.

8. García C, Rodriguez E, Do N, López-de-Castilla D, Terashima A, Gotuzzo E. Parasitosis intestinal en paciente con infección VIH-SIDA. Rev Gastroent Peru $2006 ; 26: 21-24$

9. Feitosa G, Bandeira AC, Sampaio DP, Badaro R, Britres C. High prevalence of giardiasis and strongyloidiasis among HIV infected patients in Bahia, Brazil. Braz J Infec Dis 2001; 5:339-344.

10. Wuhib T, Silva TM, Newman RD, Garcia LS, Pereira MLD, Chaves CS, et al. Cryptosporidial and microsporidial infections in human immunodeficiency virus-infected patients in Northeastern Brazil. J infect Dis 1994; 170:494-497.

11. Moura H, Fernandes O, Viola JP, Silva SP, Passos HR, Lima DB. Enteric parasites and HIV infection: occurrence in AIDS patients in Rio de Janeiro, Brazil. Mem Inst Oswaldo Cruz 1989; 527-533.

12. Cimerman S, Cimerman B, Lewi DS. Prevalence of intestinal parasitic infections in patients with acquired immunodeficiency syndrome in Brazil. Inter J Infect Dis 1999; 3:203-206.

13. Sadrael J, Rizvi MA, Baveja UK. Diarrhea, CD4+ cell counts and opportunistic protozoa in Indian HIV-infected patients. Parasit Res 2005; 97:270-273.

14. Bachur TPR, Vale JM, Coêlho ICB, Queiroz TRBS, Chaves CS. Enteric parasitic infections in HIV/AIDS patients before and after the highly active antiretroviral therapy. Braz J Infect Dis 2008; 12:115-122.

15. Crum-Cianflone NF, Greg GMS, Sara ERN, Anuradha GMD, Michael LMD, Amy Weintrob MD, at al. Trends and causes of hospitalizations among HIV-infected persons during the late HAART era: what is the impact of CD4 cell counts and HAART use? J Acquir Immune Defic Syndr 2010; 1:248-257.

16. Instituto Brasileiro de Geografia e Estatística [Internet]. [cited Apr 2011 11] Available from: www.ibge.gov.br/cidadesat/painel/painel.php?codmun=354980.

17. National Association of Security Dealers Automated Quotation. Google Corporate. [Internet]. [cited Apr 2011 11]. Available from: http://maps.google. com.br/maps.

18. Lazzarotto A, Reichert MT, Venker C, Kramer AS, Sprinz E. HIV/aids e meia idade: avaliação do conhecimento de indivíduos da região do Vale do Sinos (RS), Brasil. Cienc Saude Coletiva 2010; 15:1185-1190.

19. Furini AAC, Schiesari Jr A, Souza MSR, Helena CC, Rossit ARB, Machado RLD Perfil das coinfecções em indivíduos soropositivos para o HIV-1 atendidos em um Hospital Escola do Noroeste Paulista, Brasil: dados preliminares. Rev Panam Infectol 2010; 13:39-42.

20. Payan C, Ducancelle A, Aboubaker MH, Caer J, Tapia M, Chauvin A, et al. Human papillomavirus quantification in urine and cervical samples using a general realtime PCR on Mx4000 and Lightcycler systems. J Clin Microbiol 2007; 45:897-901

21. Hacker MA, Leite IC, Renton A, Torres TG, Gracie R, Bastos FI. Reconstructing the AIDS epidemic among injection drug users in Brazil. Cad Saude Publica 2006; 22:751-760.

22. Cardoso LV, Marques FR, Cavasisni CE, Almeida MC, Nair BA, Gongóra DVN, et al. Correlation of intestinal parasitic pathogens in HIV-seropositive adult with and without diarrhea in Northeast region of São Paulo State, Brazil. Rev Panamer Infectol 2004; 6:8-11.

23. Schnack FJ, Fontana LDM, Barbosa PR, Silva LSM, Baillargeon CMM, Barichello T, et al. Enteropatógenos associados com diarréia infantil ( $<5$ anos de idade) em amostra a população da área metropolitana de Criciúma, Santa Catarina, Brasil. Cad Saude Publica 2003; 19:1205-1208.

24. Gonçalves ACM, Gabbay YB, Mascarenhas JD, Yassaka MB, Moran LC, Fraga VD, at al. Calicivirus and Giardia lamblia are associated with diarrhea in HIV-seropositive patients from Southeast Brazil. Am J Trop Med Hyg 2009; 81:463-466.

25. Caccio SM, Ryan U. Molecular epidemiology of giardiasis. Mol Biochem Parasitol 2008; 160:75-80.

26. Anand L, Dhanachand C, Brajachand N. Prevalence and epidemiologic characteristics of opportunistic and non-opportunistic intestinal parasitic infections in HIV positive patients in Manipur. J Commun Dis 1998; 30:19-22.

27. Hashmey R, Genta RM, Branco J. Parasites and Diarrhea: Protozoans e Diarrhea. J Travel Med 1997; 4:17-31.
28. Carvalho HB, Bueno R. Prevalência da infecção pelo HIV e seus determinantes em sete cidades brasileiras - Projeto Brasil, São Paulo: 1997. [Relatório final apresentado ao Ministério da Saúde]. Mimeo; 32p.

29. Victoria MB, Victoria FS, Torres KL, Kashima S, Covas DT, Malheiro A Epidemiology of HIV/HCV coinfection in patients cared for at the Tropical Medicine Foundation of Amazonas. Braz J Infect Dis 2010; 14:135-140.

30. Spradling PR, Richardson JT, Buchacz K, Moorman ACBSN, Finelli L, Bell BP et al. Trends in hepatitis $\mathrm{C}$ virus infection among patients in the HIV Outpatient Study, 1996-2007. J Acquir Immune Defic Syndr 2010; 53:388-396.

31. Pereira RARA, Mussi ADH, Silva VCA, Souto FJD. Hepatitis B Virus infection in HIV-positive population in Brazil: results of a survey in the state of Mato Grosso and a comparative analysis with other regions of Brazil. BMC Infect Dis 2006; 6:34.

32. French MA. HIV/AIDS: immune reconstitution inflammatory syndrome: a reappraisal. Clin Infect Dis 2009; 48:101-107.

33. Lane HC. Pathogenesis of HIV infection: total CD4+ T-cell pool, immune activation, and inflammation. Trop HIV Med 2010; 18:2-6.

34. Kulkarni SV, Kairon R, Sane SS, Padmawar PS, Kale VA, Thakar MR, et al. Opportunistic parasitic infections in HIV/AIDS patients presenting with diarrhoea by the level of immunesuppression. Indian J Med Res 2009; 130:63-66.

35. Pózio E, Gómez-Morales MA. The impact of HIV-protease inhibitors on opportunistic parasites. Trends Parasitol 2005; 21:58-63.

36. Rossit AR, Almeida MT, Nogueira CA, Costa-Oliveira JG, Barbosa DM, Moscardini AC, et al. Bacterial, yeast, parasitic, and viral enteropathogens in HIV-infected children from São Paulo State, Southeastern Brazil. Diag Microbiol Infect Dis 2007; 57:59-66.

37. Assefa S, Erko B, Medhin G, Assefa Z, Shimelis T. Intestinal parasitic infections in relation to HIV/AIDS status, diarrhea and CD4 T-cell count. BMC Infect Dis 2009; 9:155

38. Gopinath R, Ostrowski M, Justement SJ, Fauci AS, Nutman TB. Filarial infections increase susceptibility to human immunodeficiency virus infection in peripheral blood mononuclear cells in vitro. J Infect Dis 2000; 182:1804-1808.

39. Delobel P, Signate A, El Guedj M, Couppie P, Gueye M, Smadja D, et al. Unusual form of neurocysticercosis associated with HIV infection. Eur J Neuro 2004; 11:55-58.

40. Keiser PB, Nutman TB. Strongyloides stercoralis in the Immunocompromised Population. Clin Microbiol Rev 2004; 17:208-217.

41. Nunn MF, Marsh JW. Human immunodeûciency virus type $1 \mathrm{Nef}$ associates with a member of the p21-activated kinase family. J Virol 1996; 70:6157-6161.

42. Mark EV, James BL. Strongyloides spp. WormBook, editor. The C. elegans Research Community. WormBook [Internet]. 2007- [cited jun 2005 25]. Available from: http:www.wormbook.org.

43. Del Carpio D, Rodríguez D, Vildósola H. Strongyloides stercoralis hyperinfection syndrome in a patient with human immunodeficiency virus (HIV) infection report of a case and review of the literature. Rev Gastroenterol Peru $1995 ; 15: 290-295$.

44. Oldfield EC. Evaluation of chronic diarrhea in patients with human immunodeficiency virus infection. Rev Gastroenterol Disord 2002; 2:176-188. 